\title{
Pyloric stenosis in the Oxford Record Linkage Study Area
}

\author{
PHILIPPA ADELSTEIN and JEAN FEDRICK \\ From the Unit of Clinical Epidemiology, Department of the Regius Professor of Medicine, University of Oxford
}

Summary. The files of the Oxford Record Linkage Study were employed to identify 220 infants presenting with infantile hypertrophic pyloric stenosis (IHPS) in the 6-year period 1966 to 1971 . Information on these infants was obtained from birth certificates and maternity notes. The overall incidence was 2.5 per 1000 livebirths. There was a distinct seasonal variation, with highest incidence to infants born in the third quarter of the year as well as variation in incidence with area: the cities had much lower rates of IHPS than the adjacent rural or small urban areas. It was shown that the rates in the south and east of the area studied were far greater than in the north and west.

In the present study there was no excess of primiparae, the peak maternal age group was 20 to 24; there was a slight excess of parents of social classes I and II; and a significant association with mothers who were Rhesus negative. The rate of IHPS among sibs was 85 per 1000 . Though there was the usual correlation with the male sex $(M: F$ ratio $=5.5: 1)$, there was no variation with birthweight and only among the females was an association found with prolonged gestation. There appeared to be an inverse relation between gestation and age on admission to hospital.

The disease of infantile hypertrophic pyloric stenosis (IHPS) has become so amenable to present methods of treatment that there have been relatively few studies designed to elucidate the causes of the disorder. One of the major drawbacks to any study of this kind is that the condition generally manifests itself after discharge from maternity hospital. Thus any information on factors connected with the relevant pregnancy and social background must either be obtained from retrospective inquiry of the mother or from a procedure of linking with the records from the relevant maternity hospital or domiciliary midwife. The problem, too, of obtaining an unbiased control population can often be extremely time consuming. The present study has the advantage of employing the data banks of the Oxford Record Linkage Study and in a sense may be considered to be prospective.

Pyloric stenosis had been described in the medical reports of the 18th century (Blair, 1717; Weber,

Received 26 January 1976.
1758; Armstrong, 1777), but was first recognized as a clinical syndrome after a description of 5 cases by Hirschsprung (1888) in Copenhagen. At the turn of the century several types of surgical procedure were attempted with varying degrees of success, until in 1912 Rammstedt developed a very simple procedure which has remained one of the most satisfactory surgical operations to this day, with an extremely low associated mortality. Nevertheless there are a few paediatricians who still prefer management by medical means.

The incidence within the British Isles has generally been reported as of the order of 2 to 3 per 1000 livebirths (Table I). The only other European areas recorded as having incidences of over 1 per 1000 are Gothenburg in Sweden and Budapest in Hungary. The rate in the southern countries of Europe is apparently very low. The one study from Malta (Cachia and Fenech, 1966) suggested that the rate there was as high as 0.9 because of the intermingling of races resulting from the presence of British servicemen on the island. In the middle- 
TABLE I

REPORTED INCIDENCES OF PYLORIC STENOSIS

\begin{tabular}{|c|c|c|c|c|c|}
\hline \multirow{2}{*}{ Author } & \multirow{2}{*}{ Area } & \multirow{2}{*}{$\begin{array}{c}\text { Years } \\
\text { Studied }\end{array}$} & \multirow{2}{*}{$\begin{array}{c}\text { Total } \\
\text { Births }\end{array}$} & \multicolumn{2}{|c|}{ Pylorics } \\
\hline & & & & No. & Inc. $\%$ \\
\hline $\begin{array}{l}\text { British Isles } \\
\text { Davison (1946) } \\
\text { MacMahon et al (1951) } \\
\text { Lawson (1951) } \\
\text { McLean (1956) } \\
\text { Smith (1960) } \\
\text { Dodge (1970) }\end{array}$ & $\begin{array}{l}\text { Newcastle upon Tyne } \\
\text { Birmingham } \\
\text { Dundee } \\
\text { Aberdeen } \\
\text { Edinburgh } \\
\text { Belfast }\end{array}$ & $\begin{array}{l}1939-42 \\
1940-49 \\
1940-46 \\
1938-53 \\
1950-58 \\
1957-69\end{array}$ & $\begin{array}{r}17457 \\
194216 \\
21288 \\
110394 \\
66966 \\
107244\end{array}$ & $\begin{array}{r}49 \\
578 \\
32 \\
369 \\
205 \\
289\end{array}$ & $\begin{array}{l}2.8 \\
3.0 \\
1.5 \\
3.3 \\
3.0 \\
2.6\end{array}$ \\
\hline $\begin{array}{l}\text { Rest of Europe } \\
\text { Wallgren (1941) } \\
\text { Wallgren (1960) } \\
\text { Czeizel (1972) } \\
\text { Cachia and Fenech (1966) }\end{array}$ & $\begin{array}{l}\text { Gothenburg } \\
\text { Gothenburg } \\
\text { Budapest } \\
\text { Malta }\end{array}$ & $\begin{array}{l}1934-40 \\
1950-59 \\
1962-67 \\
1952-64\end{array}$ & $\begin{array}{r}25642 \\
58231 \\
108966 \\
100655\end{array}$ & $\begin{array}{r}102 \\
116 \\
159 \\
89\end{array}$ & $\begin{array}{l}4.0 \\
2.0 \\
1.5 \\
0.9\end{array}$ \\
\hline $\begin{array}{l}\text { Rest of world } \\
\text { Field (1951) } \\
\text { Gharib (1964) } \\
\text { Laron (1955) } \\
\text { Center for Disease Control (1974) }\end{array}$ & $\begin{array}{l}\text { Malaya } \\
\text { Iran } \\
\text { Israel } \\
\text { Atlanta, USA }\end{array}$ & 1956-62 & $\begin{array}{c}39875 \\
\text { NS }\end{array}$ & $\begin{array}{l}0 \\
3\end{array}$ & $\begin{array}{l}0.0 \\
0.1 \\
0.5\end{array}$ \\
\hline Laron and Horne (1957) & $\begin{array}{l}\text { (White) } \\
\text { Pittsburg, USA } \\
\text { (White) } \\
\text { (Black) }\end{array}$ & $\begin{array}{l}1968-72 \\
1945-55\end{array}$ & $\begin{array}{c}\text { NS } \\
127029 \\
22809\end{array}$ & $\begin{array}{r}150 \\
153 \\
11\end{array}$ & $\begin{array}{l}1.5 \\
1.2 \\
0.5\end{array}$ \\
\hline
\end{tabular}

NS $=$ not stated

east, both Iran (Gharib, 1964) and Turkey (Eckstein, 1940) report extremely low rates.

In the United States there are very clear racial differences: in Pittsburgh, Laron and Horne (1957) found the incidence among white infants to be 1.2 compared to 0.5 among black infants. Similar figures from Metropolitan Atlanta for 1968-72 are even more extreme at 1.5 and 0.2 (Center for Disease Control, December 1974). A study of 13000 Negro infants in Nashville, Tennessee, however, produced an incidence as high as 0.9 (Hara et al, 1966). In Hawaii a study by Shim et al (1970) over the years 1942 to 1966 showed that whereas the incidence among Caucasians was 1.9, that among those of Japanese origin was 0.5 , and among 11000 Chinese infants there were no cases at all. Unfortunately there are no studies on the incidence of the lesion in the countries of the British Commonwealth, though there is a report that it is extremely rare among children of Australian aboriginees (Watson, 1956).

There are varying reports as to the secular variation of the disease. In Gothenburg (Wallgren, $1941,1960)$ there appears to have been a halving of the incidence from 1934 to 1959, and a decrease in incidence from 3.1 to 2.2 was shown in Belfast over the years 1957 to 1969 . In Birmingham, however, MacMahon et al (1951) showed an increase from 2.5 in the years $1940-1944$ to 3.4 in the years 1945 to 1949. A similar increase was shown in Aberdeen (McLean, 1956), with incidences of 2.3, 2.7, 3.6, and
4.5 in each 4-year period from 1938 to 1953 . More recently Murfin (1974) has reported a pronounced increase in the small island of Barbados.

As well as the well-substantiated excess of males with the lesion, apparent in all countries and allo races, it had been generally assumed by physicians that IHPS was predominantly a disease of the first born. It was Still in 1927 who first attempted to test this assumption with 400 cases admitted to Great Ormond Street Hospital. After inspecting various control groups, he came to the conclusion that there was indeed an excess of first-births in his series. This finding was substantiated by Cockayne and Penrose (1943); by Ford et al (1941) in Toronto; McQuaid and Porrit (1950) in Oxford; McKeown et al (1951a) in Birmingham; Shim et al (1970) in Hawaii; Dodge (1970) in Belfast; and Danis (1957) in Brussels. Lack of a positive association has, however, been reported in an almost equal number of studies: Delprat and Pflueger (1948) and Benson and Warden (1957) in the USA; Dougall (1969) in Glasgow; Czeizel (1972) in Budapest, and Huguenard and Sharples (1972) also in the USA. This last study was of interest in that the authors analysed some 55 completed sibships identified by the presence of at least 1 case of pyloric stenosis. They concluded that the position of affected cases within the sibships did not differ from that expected by chance.

One of the major effects noted in epidemiological studies has been the increased risk of recurrence 
within families. This topic is examined in the present study only for sibs born within the period 1965 to 1972. Record linkage techniques were employed to examine whether the index infants, their sibs, or their mothers showed an increased risk of hospital admission or death from any other cause.

\section{Subjects and methods}

The Oxford Record Linkage Study (Acheson, 1967; Baldwin, 1972) was started in 1962 and from 1966 to 1971 the area covered included Oxfordshire and that part of Berkshire within the Oxford Regional Hospital Board area. The two cities of Oxford and Reading are included, but the rest of the area is largely rural with several town centres, and a total population of some 800000 .

The following data are collected: (a) information on all deliveries in the area. (In the case of hospital births, detailed description of pregnancy and delivery, of any abnormality or illness in the baby, and certain social factors, are abstracted by trained clerks from the hospital notes onto set forms. For domiciliary deliveries the same information is abstracted from the midwife's notes.) (b) Birth certificates of all deliveries to women resident in the area. (c) Death certificates of all persons resident in the area. (d) Details of all general and psychiatric hospital admissions in the area.

The present study began by considering all infant admissions for pyloric stenosis in the period 1966 to 1971.

Some infants were admitted with an initial diagnosis of vomiting, diarrhoea, or wasting, though after treatment the diagnosis was revised to pyloric stenosis. For this reason the discharge diagnoses were also checked. All the codes and the patient's ages were checked and, where necessary, the original notes referred to.

Any cases for whom a birth certificate had not been received (i.e. were not infants of mothers normally resident in the area) were then excluded. There were then 220 confirmed cases with only two infants being treated medically, the rest undergoing Rammstedt's pyloromyotomy. Eight of these cases had in fact been delivered outside the area and only appear in our series when data solely abstracted from birth certificates are considered.

For the initial analyses the index cases were compared with the total population at risk, but for more detailed assessment of factors such as type of pregnancy, delivery, and neonatal morbidity each of the 212 cases for which maternity data were available was matched with 3 livebirth controls of the same social class, parity, maternal age, place of delivery, legitimacy, and year of delivery. In the event there were 7 index cases for which no matched controls were available as parity or maternal age was unknown, leaving a control series of $615(205 \times 3)$ maternities.

From the identifying characteristics of the mothers (names, date of birth, etc), it was possible to find details of all other deliveries to those women in the period 1965 to 1972. In this way a group of sibs was identified. The files of hospital admissions and deaths were then scanned to identify any admissions to the index cases, controls, their mothers, and their sibs.

\section{Results}

\section{Incidence}

Over the 6-year period 1966 to 1971 there were 88658 livebirths delivered to women whose home address was in the area, giving an overall incidence of 2.48 per 1000 livebirths. Considering only those deliveries which actually took place within the area, the rate is 2.56 per 1000 livebirths (222/82761).

Of the 220 cases 186 were male and 34 female, giving a male to female ratio of 5.47:1. In terms of the population at risk this gives an incidence of 4.1 per 1000 male livebirths and only 0.8 per 1000 female livebirths.

In all there were 7 pairs of twins involving 8 index infants: i.e. 1 in 28 of the series was a twin. This is almost twice as many as would be expected from the proportion of population livebirths which were twins ( 1 in 52), but the difference is not significant.

\section{Variation with place of residence}

As can be seen from Table II there is some variation in incidence with the type of area in which the mother resides, in that there is a lower rate of IHPS if the infant resides in a city compared with the rest of the area. When looked at according to the new reorganized local authority areas (Fig. 1) the incidences to the south-east are much higher than those in the north-west, but the two cities still have incidences much lower than the surrounding areas, the incidence in the city of Oxford being exceptionally low. The highest incidence was found in the small town of Wallingford with 6 cases in 642 births (i.e. 9.3 per 1000 ).

TABLE II

VARIATION IN INCIDENCE ACCORDING TO PLACE OF RESIDENCE OF MOTHER

\begin{tabular}{l|c|c|c}
\hline $\begin{array}{c}\text { Area of } \\
\text { Residence }\end{array}$ & $\begin{array}{c}\text { No. Index } \\
\text { Cases }\end{array}$ & $\begin{array}{c}\text { Total } \\
\text { Livebirths }\end{array}$ & Incidence \\
\hline City & 47 & 23749 & 1.98 \\
Small town & 49 & 16762 & 2.92 \\
Rural areas & 124 & 48147 & 2.58 \\
\hline All & 220 & 88658 & 2.48 \\
\hline
\end{tabular}

$(0.25<\mathrm{P}<0.1)$

\section{Variation with time}

Table III shows the significant seasonal variation in month of birth with a peak incidence of IHPS in late July. This effect is even more extreme among the small number of females in the series. 


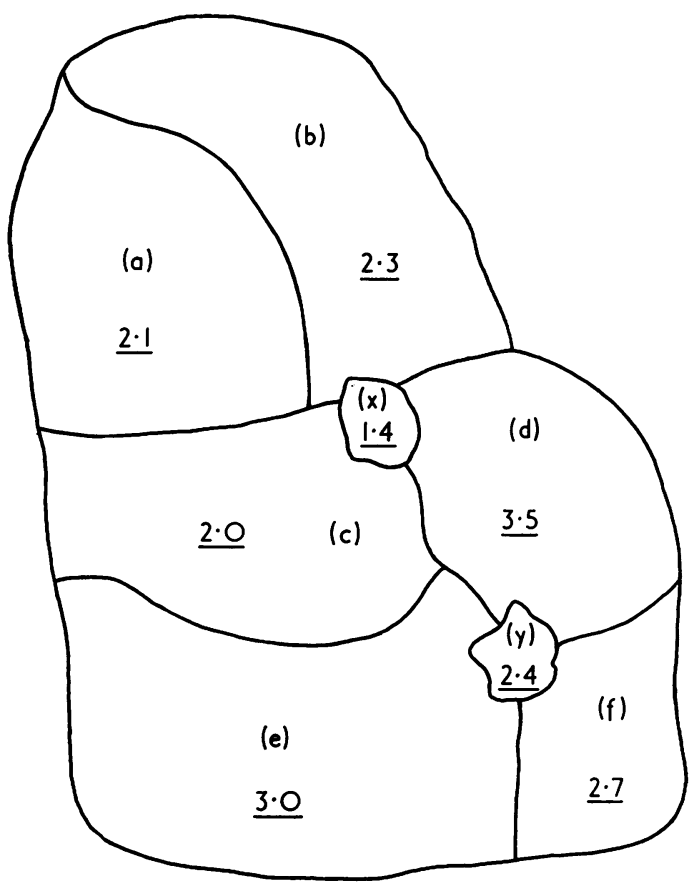

FIG. 1. Incidence of IHPS by local authority area; (a) West Oxfordshire, (b) Cherwell, (c) Vale of the White Horse, (d) Wallingford, (e) Newbury, (f) Wokingham, (x) Oxford County Borough, (y) Reading County Borough.

TABLE III

QUARTER OF BIRTH OF CASES OF PYLORIC STENOSIS

\begin{tabular}{l|rr|c}
\hline \multicolumn{1}{c|}{ Date of Birth } & \multicolumn{2}{c|}{ No. Index Cases* } & Incidence \\
\cline { 2 - 3 } January-March & 43 & $(6)$ & 1.87 \\
April-June & 50 & $(8)$ & 2.12 \\
July-September & 74 & $(14)$ & 3.33 \\
October-December & 53 & $(6)$ & 2.56 \\
\hline Total & 220 & $(34)$ & 2.48 \\
\hline
\end{tabular}

$\chi^{2}=11.3 ;$ d.f. $=3 ; P<0.02$.

Edward's test (1961) for seasonality: $\chi^{2}=6.4$; d.f. $=2 \mathrm{P}<0.05$. $\sigma=42^{\circ}$ i.e. minimum is end of January, maximum is end of July.

* No. of females in parentheses.

TABLE IV

YEAR OF BIRTH OF CASES OF IHPS

\begin{tabular}{|c|c|c|c|c|}
\hline Year & $\begin{array}{l}\text { No. Livebirths } \\
\text { at risk }\end{array}$ & $\begin{array}{l}\text { No. of Cases } \\
\text { IHPS* }\end{array}$ & $\begin{array}{l}\mathbf{M}: \mathbf{F} \\
\text { ratio }\end{array}$ & Incidence \\
\hline $\begin{array}{l}1965 \\
1966 \\
1967 \\
1968 \\
1969 \\
1970 \\
1971\end{array}$ & $\begin{array}{l}15286 \\
15131 \\
14804 \\
14889 \\
14640 \\
14667 \\
14527\end{array}$ & $\begin{aligned} 8 & (0) \\
36 & (4) \\
46 & (9) \\
31 & (1) \\
40 & (6) \\
32 & (6) \\
27 & (8)\end{aligned}$ & $\begin{array}{r}8.0: 1 \\
4.1: 1 \\
30.0: 1 \\
5.7: 1 \\
4.3: 1 \\
2.4: 1\end{array}$ & $\begin{array}{l}-\overline{2.40} \\
3.11 \\
2.08 \\
2.73 \\
2.18 \\
-\end{array}$ \\
\hline
\end{tabular}

*No. of females in parentheses.
The method by which the cases were ascertained (i.e. the hospital admissions over the years 1966-71) results in the identification of a few infants born in 1965 and incomplete ascertainment in 1971 (Table IV). Omitting these two years there is a certain amount of year-to-year variation, but this is not statistically significant. Note the more erratic variation in the number of female affected cases.

A test for clustering in date of birth and area of residence proved negative using both the method of Knox (1963, 1964) applied to small local authority areas, and that of Ederer, Myers, and Mantel (1964).

\section{Hospital of delivery}

From Table $\mathrm{V}$ it can be seen that there is a striking variation with the size of the hospital in which the infant had been delivered. There is a higher incidence in domiciliary than hospital deliveries, but the incidence in the small hospitals (i.e. those without a consultant obstetrician on the staff) closely resembles that of the domiciliary deliveries. This effect is independent of the variation in incidence with the place of residence of the mother.

TABLE V

SIZE OF HOSPITAL IN WHICH INDEX INFANT WAS DELIVERED

\begin{tabular}{l|c|c|c}
\hline \multicolumn{1}{c|}{ Place of Delivery } & $\begin{array}{c}\text { No. Cases } \\
\text { IHPS }\end{array}$ & $\begin{array}{c}\text { Total } \\
\text { Livebirths }\end{array}$ & Incidence \\
\cline { 1 - 3 } $\begin{array}{l}\text { Large maternity } \\
\text { hospital }\end{array}$ & 109 & 53199 & 2.05 \\
$\begin{array}{l}\text { Small hospital } \\
\text { All hospital }\end{array}$ & 67 & 18361 & 3.65 \\
\hline $\begin{array}{l}\text { Domiciliary } \\
\text { Dom }\end{array}$ & 176 & 71560 & 2.46 \\
\hline
\end{tabular}

$\chi^{2}=17.43$ d.f. $=1$.

$\mathbf{P}<0.001$.

\section{Maternal age and parity}

Fig. 2 shows the estimated incidence according to parity (defined as the number of previous pregnancies exceeding 28 weeks' gestation). Though two recent papers by Huguenard and Sharples (1972) from the University of Michigan have shown that this type of approach may give misleading results when dealing with incomplete family sizes, most reports to date have used this method, and have concluded that the greatest risk is to the firstborn infant. It is, therefore, interesting to note that in the present series the highest incidence is in the second birth place. The risk to the third born infant is lower than to the second but still higher than to the firstborn. The most striking finding, however, is the relative absence of affected infants in the higher parities. 


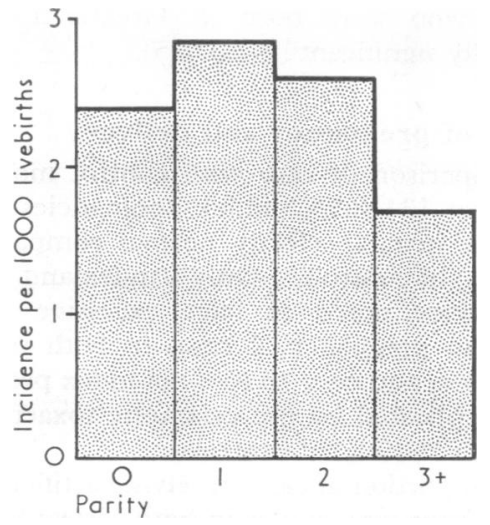

FIG. 2. Variation in incidence with parity.

Similarly, in Fig. 3 it can be seen that the incidence is highest at maternal ages 20 to 24 with a significant fall thereafter as age increases. An analysis of age and parity together adds little of note (Table VI).

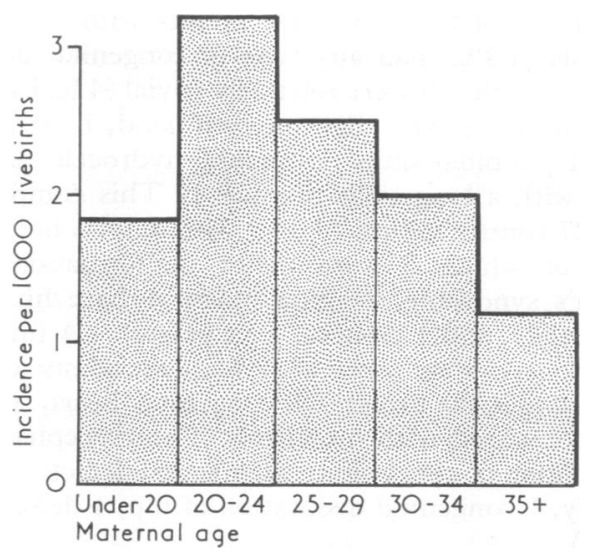

FIG. 3. Variation in incidence with maternal age.

\section{Social class}

In 1910 Rommel found a high proportion of children of physicians in his series and concluded that IHPS was a disease of the intellectual classes. Dodge (1970) in Belfast also described what he considered to be a high proportion of doctor's infants as well as an excess of children of policemen. $\mathrm{He}$ concluded that it was a disease of children whose fathers were in stressful occupations.

In the present series we have an excess of infants of fathers of upper social classes, but no clear trend is apparent in Table VII. There were only 2 children of physicians and no cases recorded as having a policeman for a father!

TABLE VII

INCIDENCE OF IHPS BY SOCIAL CLASS

\begin{tabular}{c|c|l}
\hline Social Class & No. Cases IHPS & Incidence \\
\cline { 2 - 3 } II & 18 & 2.47 \\
III & 40 & 3.56 \\
III & 89 & 2.32 \\
IV & 32 & 2.92 \\
V & 10 & 2.11 \\
Armed Forces & 12 & 2.68 \\
Students & 2 & 2.78 \\
Not known & 9 & 1.63 \\
\hline Total & 212 & 2.54 \\
\hline
\end{tabular}

\section{Maternal blood group}

Dodge (1974) reported a striking excess of index mothers of blood groups $\mathrm{O}$ and B in Belfast, but in the present study (Table VIII) we find no significant variation in the distribution of $\mathrm{ABO}$ blood groups compared with the whole maternity population. In contrast there is a consistent excess of women who were Rhesus negative $(P<0.02)$.

\section{Legitimacy}

Only 9 of the $220(4.8 \%)$ index cases were recorded on the birth certificate as being illegitimate.

TABLE VI

DISTRIBUTION OF PYLORIC CASES BY MATERNAL AGE AND PARITY

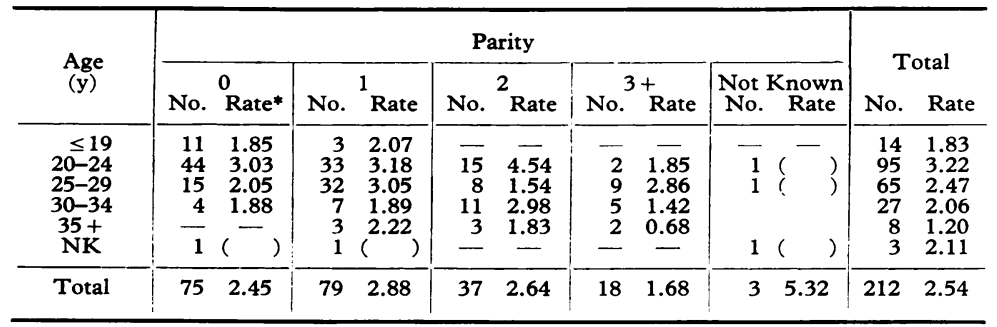

* Rates per 1000 estimated livebirths (estimated livebirths at risk = 1968 livebirths $\times 6$ ). 
TABLE VIII

INCIDENCE BY MATERNAL BLOOD GROUPS

\begin{tabular}{l|cc|cc|c}
\hline \multicolumn{1}{|c|}{ ABO Group } & \multicolumn{2}{|c|}{ Rhesus + ve } & \multicolumn{2}{|c|}{ Rhesus - ve } & All Known \\
\hline A & 2.60 & $(73)$ & 2.97 & $(17)$ & 2.66 \\
B & 1.51 & $(9)$ & 5.09 & $(6)$ & 2.10 \\
AB & 2.99 & $(6)$ & 2.30 & $(1)$ & 2.87 \\
O & 2.08 & $(61)$ & 3.61 & $(22)$ & 2.34 \\
\hline All known & 2.28 & $(149)$ & 3.42 & $(46)$ & 2.53 \\
\hline
\end{tabular}

No. of cases in parentheses.

This compares with $7 \%$ of all births on our files, and while not statistically of significance, clearly suggests that IHPS is not among the many conditions which have an increased incidence among illegitimate births.

For the remaining analyses we employ for comparison the control series described earlier.

\section{Maternal religion and maternal origin}

Dodge (1970) reported an excess of births to Protestants in his Belfast study, but in the present series, with controls matched for parity, there is no demonstrable variation with religion (Table IX).

Similarly, with data on maternal origin (Table X) there is no clear pattern-though the excess of index

TABLE IX

MATERNAL RELIGION IN CASES AND CONTROLS

\begin{tabular}{l|c|c|c}
\hline \multicolumn{1}{c|}{ Maternal Religion } & Index Cases & Controls & Relative Risk \\
\hline Church of England & 151 & 434 & 1.04 \\
Roman Catholic & 25 & 77 & 0.97 \\
Non-conformist & 12 & 45 & 0.80 \\
Muslim & 1 & 4 \\
Bhuddist & 1 & 3 \\
Jewish & 2 & 5 \\
Other, & 1 & 3 \\
'None' & 12 & 44 & 1.00 \\
Not Stated & 205 & 615 & 0.82 \\
\hline \multicolumn{1}{|c|}{ Total } & & 1.00 \\
\hline
\end{tabular}

TABLE $\mathrm{X}$

MATERNAL PLACE OF BIRTH IN CASES AND CONTROLS

\begin{tabular}{l|c|c|c}
\hline \multicolumn{1}{c|}{ Maternal Place of Birth } & $\begin{array}{c}\text { Index } \\
\text { Cases }\end{array}$ & Controls & $\begin{array}{c}\text { Relative } \\
\text { Risk }\end{array}$ \\
\hline Oxford Record Linkage & 72 & 216 & 1.00 \\
Area & 32 & 58 & 1.66 \\
Greater London & 63 & 186 & 1.02 \\
Rest of England & 18 & 54 & 1.00 \\
Scotland, Ireland, Wales & 1 & 11 & 0.27 \\
West Indies & 3 & 10 & 0.90 \\
India and Pakistan & 5 & 15 & 1.00 \\
Europe & 1 & 13 & 0.23 \\
Rest of world & 10 & 52 & 0.57 \\
Not Stated & 205 & 615 & 1.00 \\
\hline \multicolumn{1}{c|}{ Total } & & & \\
\hline
\end{tabular}

mothers who were born in Greater London is statistically significant $(P<0.025)$.

\section{History of pregnancy and delivery}

A comparison of case with control mothers revealed that $134(65 \%)$ index pregnancies were recorded as being perfectly normal compared with 397 (65\%) of controls. Only 1 index and 1 control mother were noted to have excessive vomiting throughout pregnancy, 2 cases in both series had hydramnios, and only $13(6 \%)$ of index pregnancies were complicated by pre-eclamptic toxaemia compared with $56(9 \%)$ of controls.

The proportion of cases receiving artificial induction of labour was similar in both series; lengths of labour were identical. The mode of delivery was unremarkable, the only factor of note being the 4 cases delivered before arrival at maternity hospital (compared with 3 controls). As to position on delivery, again there was no difference between the cases and their controls.

\section{Abnormality in infant}

Only 10 of the 205 index infants with matched controls $(4.9 \%)$ had any type of congenital defect noted at birth: all were relatively trivial (4 had small birth marks, 1 extra digit on each hand, 1 extra earo lobe, 1 pilonidal sinus, 1 bilateral hydrocele, and penis with a long tight prepuce). This compared with 27 control infants $(4.4 \%)$ with defects noted at birth of which 5 were major malformations (1 Down's syndrome, 2 spina bifida, 1 hare lip and cleft palate, and 1 bilateral cleft palate). A further 2 index cases were noted at subsequent admission to have congenital defects ( 1 congenital heart, 1 bat ear), compared with 6 controls (1 microcephaly, 1 malrotation of gut, 1 ventricular septal defect, 1 syndactyly, 1 congenital dislocation of hip, 1 deformed finger).

Not only was the proportion of defects in the index series unremarkable, there was also a lack of significant morbidity in the neonatal period, though it might be worth noting that 3 index infants had systolic murmurs ( 1 control), only 2 had jaundice (18 controls) and 5 began vomiting while at the maternity hospital (3 controls). Only 3 index infants were diagnosed as having a pyloric tumour before discharge from maternity hospital.

Apart from the index admission, there were 48 other admissions to infants who had had pyloric stenosis compared with 82 to controls. The excess was mainly the result of the increased number of index cases with tonsil and adenoid problems, otitis media or hernias (Table XI). Four control infants 
TABLE XI

CAUSES OF HOSPITAL ADMISSION OF INDEX CASES AND CONTROLS

\begin{tabular}{l|c|c}
\hline \multicolumn{1}{c|}{ Cause of Hospital Admission } & $\begin{array}{c}\text { Index Case } \\
(\mathbf{N}=205)\end{array}$ & $\begin{array}{c}\text { Control } \\
(\mathbf{N}=615)\end{array}$ \\
\hline Accidents & 7 & 8 \\
Hernias & 10 & 15 \\
Tonsils and adenoids & 7 & 8 \\
Respiratory disease & 5 & 10 \\
Otitis media & 3 & 2 \\
Urinary tract infections & 0 & 0 \\
Gastrointestional infections & 0 & 5 \\
Feeding problems & 2 & 1 \\
Poisoning & 3 & 9 \\
Other & 11 & 24 \\
\hline Total infants admitted & 48 & 82 \\
\hline
\end{tabular}

died after the neonatal period, 2 of severe malformations, but all index cases survived this period.

\section{Birthweight and gestation}

In the Hawaii study (Shim et al, 1970), birthweight was positively correlated with pyloric stenosis $(P<0.001)$. Czeizel in Budapest (1972) found a significant excess of affected males with birthweight more than $3500 \mathrm{~g}$, but no difference in the distribution of gestation. Other series (Dougall, 1969; Dodge, 1970) failed to find any association. Table XII shows the gestational distributions of the cases and controls. There is little of note.

TABLE XII

GESTATION DISTRIBUTION OF CASES AND CONTROLS

\begin{tabular}{l|c|c|c}
\hline Gestation $(w)$ & No. Cases & No. Controls & Relative Risk \\
\hline$<37$ & 9 & 40 & 0.90 \\
$37-38$ & 27 & 72 & 1.13 \\
$39-41$ & 127 & 394 & 0.97 \\
$42+$ & 18 & 45 & 1.20 \\
Not known & 24 & 64 & 1.13 \\
\hline Total & 205 & 615 & 1.00 \\
\hline
\end{tabular}

In the tables thus far the controls have been control mothers, matched with mothers of pyloric infants. For a full investigation of possible birthweight or gestation differences, it is necessary to match the mothers on one further variable: the sex of the infant to which they gave birth. Only 146 male cases could be matched in this way (out of 173), and 29 female cases (out of 32).

The mean gestation for the index males was 40 weeks 1 day, and for their matched controls 39 weeks 5 days, the difference being clearly not significant (Table XIII). In the case of the females, however, using a t-test on the paired differences, there does seem to be a lack of premature pyloric girl infants $(0.025>P>0.01)$. The mean length of
TABLE XIII

\begin{tabular}{|c|c|}
\hline \multicolumn{2}{|c|}{ Matched pairs of same sex } \\
\hline \multicolumn{2}{|c|}{$\begin{array}{l}\text { Difference between gestations: } \\
\text { case-control } \pm S E \text { of difference }\end{array}$} \\
\hline $\begin{array}{l}\text { males: } \\
\text { females: }\end{array}$ & $\begin{array}{l}2.16 \text { days } \pm 1.8(t=1.2) \\
10.35 \text { days } \pm 4.0(t=2.6)^{*}\end{array}$ \\
\hline \multicolumn{2}{|c|}{ Difference between birthweights: } \\
\hline $\begin{array}{l}\text { males: } \\
\text { females: }\end{array}$ & $\begin{aligned} 52 g & \pm 57 g(t=0.9) \\
-31 g & \pm 120 g(t=-0.3)\end{aligned}$ \\
\hline
\end{tabular}

gestation for these index females was 40 weeks 4 days and for their matched controls, 39 weeks 1 day.

When considering the birthweight of these infants, the female cases were no heavier than their controls, the mean birthweights being $3.2 \mathrm{~kg}$ and $3.3 \mathrm{~kg}$, respectively. The mean birthweight of $3.4 \mathrm{~kg}$ was the same for both index males and their controls.

\section{Age at admission}

As can be seen from Fig. 4 the majority of infants were admitted between the 3rd and 7th week of life, with a mode at 5 weeks and median at 6 weeks. From Table XIV, however, it can be seen that the

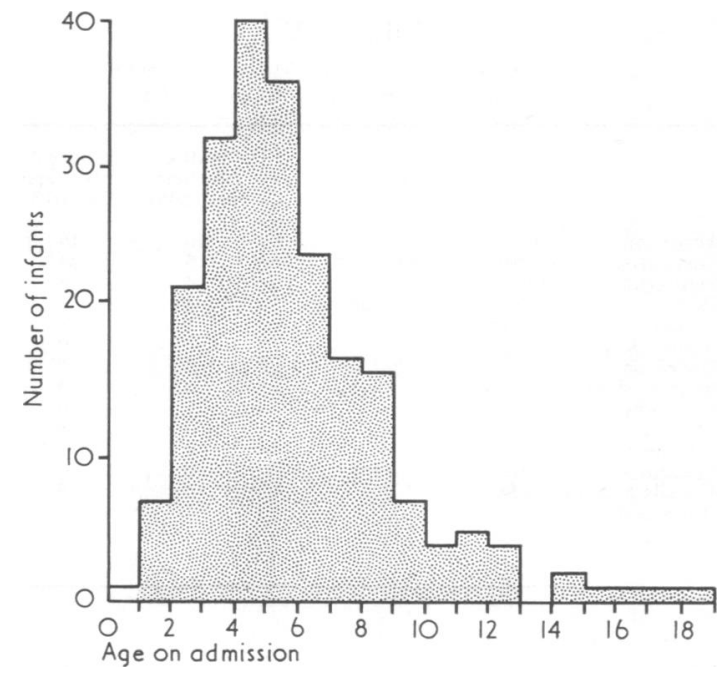

FIG. 4. Distribution of cases by age on admission.

TABLE XIV

AGE AT ADMISSION AND GESTATION

\begin{tabular}{l|c|cc}
\hline $\begin{array}{c}\text { Gestation } \\
(\mathbf{w})\end{array}$ & No. & \multicolumn{2}{|c}{ Age at Admission } \\
Median & Mean \\
\hline$<37$ & 17 & $7 \mathrm{w}$ & $51.9 \mathrm{~d}$ \\
$38-40$ & 117 & $6 \mathrm{w}$ & $39.8 \mathrm{~d}$ \\
$41+$ & 50 & $5 \mathrm{w}$ & $37.3 \mathrm{~d}$ \\
\hline
\end{tabular}


age at admission (and, presumably, the age at onset of symptoms) appears to vary with the gestation of the infant, in that the longer the infant spent in utero the earlier does his tumour tend to present.

McKeown et al (1952) had also reported that domiciliary births tend to present earlier than infants delivered in hospital, but there was no evidence of such a finding in the present study; nor was there any sex difference in age at admission.

\section{Morbidity and other pregnancies in the mothers}

As can be seen from Table XV there was little difference between index and control mothers in respect of reasons for hospital admission. Indeed the only factor in which an excess was found was in cysts and benign tumours in the female reproductive systems ( 6 cases, 5 controls).

As regards pregnancy spacing, the index infant was not conceived after a particularly long or short interval of time measured since the preceding delivery. The sibs of controls were, however, more likely to be perinatal deaths $(22 / 336=6.5 \%)$ than the sibs of the index cases $(0 / 129)$.

TABLE XV

CAUSES OF HOSPITAL ADMISSION TO MOTHERS OF INDEX CASES AND CONTROLS

\begin{tabular}{l|c|c}
\hline \multicolumn{1}{c|}{ Cause of Admission } & $\begin{array}{c}\text { Index } \\
\text { Mothers } \\
(\mathbf{N}=205)\end{array}$ & $\begin{array}{c}\text { Control } \\
\text { Mothers } \\
(\mathbf{N}=615)\end{array}$ \\
\hline Abortion & 10 & 45 \\
Cervicitis, vaginal bleeding, etc. & 5 & 24 \\
Menstrual disorder & 4 & 8 \\
Cysts in ovary, uterus, tube, or vagina & 4 & 5 \\
Urinary tract infection & 1 & 3 \\
Cholecystitis & 4 & 9 \\
Overdose & 3 & 7 \\
Anxiety/depression & 0 & 3 \\
Appendicectomy & 2 & 6 \\
Accidents & 0 & 5 \\
Benign neoplasms & 2 & 2 \\
Malignant neoplasms & 0 & 3 \\
Tonsils and adenoids & 0 & 5 \\
Otitis media & 1 & 1 \\
Thyrotoxicosis & 1 & 1 \\
Other & 7 & 22 \\
& & \\
\hline
\end{tabular}

\section{Sibs}

In all, apart from the twins, there were $127 \mathrm{sibs}$ of index cases delivered in the period 1965 to 1972 . The sex ratio among these sibs was unremarkable (Table XVI), and pyloric stenosis was confirmed in 9 (a rate of 71 per 1000). Of the 7 pairs of twins, 1 pair (MM) was concordant, and in 1 (FF) pair the cotwin was stillborn. If these data are added to those of Table XVI, one finds that 11 sibs were affected out of 134 at risk (where the concordant
TABLE XVI

SIBS OF INDEX SERIES (EXCLUDING CO-TWINS OF INDEX CASES)

\begin{tabular}{|c|c|c|c|}
\hline \multirow{2}{*}{ Sibs } & \multicolumn{2}{|c|}{ Index Case } & \multirow{2}{*}{ All } \\
\hline & Male & Female & \\
\hline $\begin{array}{l}\text { Prior to index } \\
\text { Male } \\
\text { Female }\end{array}$ & $\begin{array}{l}26(4) \\
23(1)\end{array}$ & $\begin{array}{l}3(0) \\
3(0)\end{array}$ & $\begin{array}{l}29(4) \\
26(1)\end{array}$ \\
\hline $\begin{array}{l}\text { Subsequent to index } \\
\text { Male } \\
\text { Female }\end{array}$ & $\begin{array}{l}32(4) \\
29(0)\end{array}$ & $\begin{array}{l}6(0) \\
5(0)\end{array}$ & $\begin{array}{l}38(4) \\
34(0)\end{array}$ \\
\hline $\begin{array}{l}\text { All sibs } \\
\text { Male } \\
\text { Female }\end{array}$ & $\begin{array}{l}58(8) \\
52(1)\end{array}$ & $\begin{array}{l}9(0) \\
8(0)\end{array}$ & $\begin{array}{l}67(8) \\
60(1)\end{array}$ \\
\hline
\end{tabular}

In parentheses are numbers of sibs with pyloric stenosis.

twins each contributed one sib). This gives a rate of 82 per 1000 , some 30 times that of the population as a whole.

Apart from the excess of sibs with IHPS, the other causes of hospital admission seem unremark- $\frac{\rho}{2}$ able when compared with the sibs of controls (Table XVII). Six of the index sibs had congenital defects compared with 17 controls. There were two postneonatal deaths in each series. There were no hospital admissions to the unaffected cotwins.

TABLE XVII

CAUSES OF HOSPITAL ADMISSION OF SIBS OF INDEX CASES AND CONTROLS

\begin{tabular}{l|c|c}
\hline \multicolumn{1}{c|}{ Cause of Hospital Admission } & $\begin{array}{c}\text { Sibs of } \\
\text { Index Cases }\end{array}$ & $\begin{array}{c}\text { Sibs of } \\
\text { Controls }\end{array}$ \\
\hline Accident & 3 & 5 \\
Hernias & 2 & 3 \\
Tonsils and adenoids & 3 & 2 \\
Respiratory infections & 1 & 4 \\
Otitis media & 2 & 1 \\
Urinary tract infections & 1 & 1 \\
Gastrointestinal infections & 2 & 1 \\
Feeding problems & 0 & 1 \\
Accidental poisoning, foreign body, etc. & 9 & 1 \\
Pyloric stenosis & 1 & 13 \\
Other & 127 & 320 \\
\hline Total infants & & \\
\hline
\end{tabular}

\section{Discussion}

Although several authors are agreed that there is a $\frac{D}{0}$ strong genetic component in the development of IHPS, it is generally admitted that there must also o be a strong 'environmental' factor (Knox, 1958; N Carter, 1972; McKeown et al, 1952) responsible for N much of the variation. The only person to produce a cogent theory as to the identity of this environmental factor has been Dodge (1970). On the

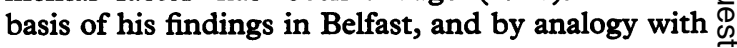


duodenal ulcer where the male preponderance is similar to that found in IHPS, Dodge has suggested that maternal stress together with the maternal genetic make-up (especially determined by the presence of blood groups $O$ and $B$ ) has resulted in an excessive production of gastrin during late pregnancy. Gastrin has been shown to cross the placenta and could be reponsible for irritating the fetal duodenum.

Certainly an association has been reported between pyloric stenosis and evidence of healed duodenal ulcer in some children. Lee (1967) suggested a process of high acid secretion producing duodenitis, in turn giving rise to superficial duodenal ulceration, this resulting in a reflex protective pylorospasm which, it is suggested, produces hypertrophy of the pyloric muscle and hence protection of the duodenum with the result that the ulcer heals.

Dodge's hypothesis has received some support from experiments in which pregnant bitches have been injected with pentagastrin and their puppies found to have duodenal ulcers and pyloric hypertrophy (Karim et al, 1974).

Thomson (1925) produced a theory with a slightly different mode of action. He suggested that the hypertrophy results from a primary incoordination of autonomic impulses resulting in overaction and hence hypertrophy. There was no suggestion of any environmental influence however.

The present study has involved the type of population hitherto neglected in epidemiological analyses of IHPS because of the relatively large geographical area with many different centres of medical care. Most previous studies have only considered cases occurring in large cities. This could be why our findings fail to substantiate those of others, notably Dodge.

Certainly the major findings of the present study: seasonal variation in time of birth, area variation, and the lack of cases delivered in large hospitals, have not been reported previously. However, an analysis of available data from the Center for Disease Control in Atlanta does appear to show a similar seasonal picture to that which we reported.

Although we have looked for evidence of abnormal stress in our index mothers, there was nothing to suggest that they were other than a completely 'normal' group of women. Nor does the blood group data of the present study support Dodge's hypothesis. We suggest that while we obviously cannot refute the possibility of maternal stress and related gastrin production being implicated, there must be some other 'environmental' agent responsible for the findings we report.
We are extremely grateful to Professor Sir Richard Doll and Dr J. A. Baldwin for helpful advice, and to Mrs Bettine Sutton, Mrs Valerie Hazell, and Mrs Jean Lawrie for clerical and secretarial assistance.

\section{REFERENCES \\ Acheson, E. D. (1967). Medical Record Linkage. Oxford Uni-} versity Press, London.

Armstrong, G. (1777). An Account of the Diseases Most Incident to Children from their Birth Till the Age of Puberty, with a Successful Method of Treating Them. London. (Cited by Dodge, 1970.)

Baldwin, J. A. (1972). The Oxford record linkage study as a medical information system. Proceedings of the Royal Society of Medicines, 65, 237-239.

Benson, C. D. and Warden, M. J. (1957). 707 cases of congenital hypertrophic pyloric stenosis. Surgery, Gynecology and Obstetrics, 105, 348-354.

Blair, P. (1717). An account of the dissection of a child. Philosophical Transactions, 353, 631.

Cachia, E. A. and Fenech, F. F. (1966). Incidence of congenital pyloric stenosis in Malta. fournal of Medical Genetics, 3, 49-50.

Carter, C. O. (1972). Genetics of infantile pyloric stenosis. In Fourth Conference on Clinical Delineation of Birth Defects, pp. 1214. Ed. by D. Bergsma. Williams and Wilkins, Baltimore.

Center for Disease Control (1974). Congenital malformations surveillance; Atlanta, Georgia D.H.E.W. Publication No. (CDC) 75-8262. U.S. Department of Health, Education and Welfare.

Cockayne, E. A. and Penrose, L. S. (1943). The genetics of congenital pyloric stenosis. Ohio fournal of Science, 43, 1-10.

Czeizel, A. (1972). Birthweight distribution in infantile pyloric stenosis. Archives of Disease in Childhood, 47, 978-980.

Danis, A. (1957). La frequence de la stenose hypertrophique due pylore n'augmente pas avec le nombre de grossesses. Acta Paediatrica, Belgica, 11, 248-252.

Davison, G. (1946). The incidence of congenital pyloric stenosis. Archives of Disease in Childhood, 21, 113-117.

Delprat, G. D. and Pflueger, O. (1948). Pyloric stenosis not a disease of firstborn. California Medicine, 68, 76.

Dodge, J. A. (1970). Infantile hypertrophic pyloric stenosis. M.D. Thesis, University of Wales.

Dodge, J. A. (1974). Proceedings: maternal factor in infantile hypertrophic pyloric stenosis. Archives of Disease in Childhood, 49, 825.

Dougall, J. (1969). Infantile pyloric stenosis : a review of 200 cases. Scottish Medical fournal, 14, 153-158.

Eckstein, A. (1940). Problem und Aufgaben der Kinderheilkunde in der Tierke. fahrbuch fiir Kinderheilkunde, 155, 16. (Cited by Wallgren, 1941.)

Ederer, F., Myers, M. H., and Mantel, N. (1964). A statistical problem in space and time. Biometrics, $20(30), 626-638$.

Edwards, J. H. (1961). The recognition and estimation of cyclic trends. Annals of Human Genetics, 25, 83-93.

Field, C. E. (1951). Congenital hypertrophic pyloric stenosis. Lancet, 2, 425-426.

Ford, N., Ross, M. A., and Brown, A. (1941). Primogeniture as an etiological factor in pyloric stenosis. American fournal of Diseases of Children, 61, 747-757.

Gharib, R. (1964). The incidence of infantile pyloric stenosis. fournal of Pediatrics, 65, 622-625.

Hara, S., Crump, E. P., and Parker, W. G. (1966). Incidence of infantile hypertrophic pyloric stenosis in the Negro infant. Fournal of the National Medical Association, 58, 250-253.

Hirschsprung, H. (1888). Falle vorn angernorener pylorrusstensose, beobachter bei sauglingen. Fahrbuch für Kinderheilkunde, 27, 61 . (Cited by Dodge, 1970.)

Huguenard, B. S. and Sharples, G. E. (1972). Incidence of congenitalpyloric stenosis within sibships. fournal of Pediatrics, 81, 45-49.

Karim, A. A., Morrison, J. E., and Parks, T. G. (1974). Report of Meeting of the Surgical Research Society: paper given on 'The role of Pentagastrin in the production of canine hypertrophic pyloric stenosis and pyloroduodenal ulceration'. British Journal of Surgery, 61, 327-337. 
Knox, G. (1958). On the nature of the determinant of congenital pyloric stenosis. British fournal of Preventive and Social Medicine, 12, 188-192.

Knox, G. (1963). Detection of low intensity epidemicity-application to cleft lip palate. British Fournal of Preventive and Social Medicine, 17, 121-130.

Knox, G. (1964). Epidemiology of childhood leukaemia in Northumberland and Durham. British fournal of Preventive and Social Medicine, 18, 17-25.

Laron, Z. (1955). Incidence of hypertropic pyloric stenosis in various Jewish communities in Israel. Acta Paediatrica, 44, 40-60.

Laron, Z. and Horne, L. M. (1957). Incidence of pyloric stenosis. American Fournal of Diseases of Childhood, 84, 151-154.

Lawson, D. (1951). The incidence of pyloric stenosis in Dundee. Archives of Diseases in Childhood, 26, 616-617.

Lee, M. (1967). Pyloric channel syndrome. Proceedings of the Royal Society of Medicine, 60, 1-3.

McKeown, T., MacMahon, B., and Record, R. G. (1951a). The familial incidence of congenital pyloric stenosis. Annals of Human Genetics, 16, 260-281.

McKeown, T., MacMahon, B., and Record, R. G. (1951b). The incidence of congenital pyloric stenosis related to birth rank and maternal age. Annals of Eugenics, 16, 249-259.

McKeown, T., MacMahon, B., and Record, R. G. (1952). Evidence of port-natal environmental influence in the aetiology of infantile pyloric stenosis. Archives of Disease in Childhood, 27, 386-390.

McLean, M. (1956). The incidence of infantile pyloric stenosis in the North east of Scotland. Archives of Disease in Childhood, 31, $481-482$.
MacMahon, B., Record, R. G., and McKeown, T. (1951). Congenital pyloric stenosis-An investigation of 578 cases. British Medical Fournal, 5, 185-192.

McQuaid, J. N. and Porrit, B. E. (1950). Infantile pyloric stenosis, review of 100 cases treated by Ramstedt's operation. Lancet, 1, 201-204.

Murfin, D. E. (1974). Changing incidence of congenital pyloric stenosis in Barbados. British Medical fournal, 1, 198.

Rammstedt, C. (1912). Zur operation der angerborenenen pylorusstenose. Medizinische Klinik, 8, 1702-1703.

Rommel, O. (1910). In discussion of paper by Ibrahim, J. Münchener medizinische Wochenschrift, 57, 1154.

Shim, W. K. T., Campbell, A., and Wright, S. W. (1970). Pyloric stenosis in the racial groups of Hawaii. Fournal of Pediatrics, 76, 89-93.

Smith, I. McD. (1960). Incidence of intussuception and congenital hypertrophic pyloric stenosis in Edinburgh children. British Medical fournal, 1, 551-552.

Still, G. F. (1927). Place in family as a factor in disease. Lancet, 2, 795 and 853.

Thomson, J. (1925). Clinical Study and Treatment of Sick Children 4th ed., p. 302 . Oliver and Boyd, Edinburgh.

Wallgren, A. (1941). Incidence of hypertrophic pyloric stenosis. American fournal of Diseases of Children, 62, 751-756.

Wallgren, A. (1960). Is the rate of pyloric stenosis declining ? Acta Paediatrica Scandinavica, 49, 530-535.

Watson, J. (1956). Letters to the Editor. Lancet, 2, 517.

Weber, C. (1758). Inaug. Dis., Gottingen. Translated by G. F. Still (1931). In History of Paediatrics. Oxford University Press, London. 